\title{
SOIL POLLUTION WITH HEAVY METALS IN INDUSTRIAL AND AGRICULTURAL AREAS: A CASE STUDY OF OLKUSZ DISTRICT
}

\author{
Paweł Miśkowiec, Anna Laptaś, Katarzyna Zięba \\ Department of Environmental Chemistry \\ Jagiellonian University in Kraków
}

\begin{abstract}
Soil contamination of areas covered by industrial plants and farms is one of the major environmental problems whose weight is underestimated in Poland and Europe. Such regions are usually not as exposed to direct pollution as highly urbanized industrial areas. On the other hand, they are usually less strictly monitored than protected areas. The District of Olkusz, an example of such a region, is characterized by well-developed agriculture, regressing local industry and growing tourism industry. However, it borders with Silesia, a heavily industrized area.

The study reports the condition of arable soils in Olkusz District in terms of their contamination with lead, cadmium, zinc and copper. The atomic absorption spectrometry (AAS) method was used to determine the concentrations of the metallic elements. The parameters like $\mathrm{pH}$, content of the clay fraction and content of organic matter have been also taken in consideration to assess the bioavailability of the metals.

The analytical results showed that, despite the decreasing impact of the local industry, levels of concentration of all the studied metals are significantly higher than their average concentration in Polish soils. Moreover, all the calculated Pearson correlation coefficients between concentrations of the metals were above 0.9 , which means they correlate each other strongly. The impact of the local pollutants (mainly Bukowno smelter) in connection with the proximity of the Silesia and the high vulnerability for contamination of the soils precludes agricultural use of the ground in at least half of the cases.
\end{abstract}

Key words: soils, lead, cadmium, zinc, copper, atomic absorption spectrometry.

Pawel Miskowiec, PhD, Department of Environmental Chemistry, Jagiellonian University, Gronostajowa 3, 30-387 Kraków, Poland, e-mail: miskowie@chemia.uj.edu.pl 


\section{INTRODUCTION}

One of the main environmental impacts of industry is the progressive change in the chemical composition of ecosystems located around emission sources. Continuous release of heavy metals from anthropogenic sources causes significant changes in the biogeochemical cycle of those elements. Toxic metals, including cadmium or lead, can easily penetrate the crops and be incorporated in the food chain. Their presence in living organisms causes widely described inhibition of important enzymes in the metabolite pathways, which leads to many metabolic diseases (WaAlKes 2000, SATARUG et al. 2003, CHоI et al 2012). In addition, the accumulation of heavy metals in plants causes their stress reaction, which entails noticeable changes in the chemical composition, mainly through the accumulation of amines - betaine, putrescine, etc. (Bergmann et al. 2001, Solanki, Dhankhar 2011). However, also microelements like zinc and copper appearing in high amounts in a diet and compounded by their ability to accumulate can cause diseases like anaemia or damage to kidneys and the liver (HAAR, BAYARD 1971, DAS et al. 1997, Bergmann et al. 2001). All the metals mentioned above are emitted to the environment mainly by industrial combustion processes $(\mathrm{Cd}, \mathrm{Pb})$ and by the mass use of pesticides and fertilizers - Zn, Cd, Cu (HAAR, BAYARD 1971, Kim, Fergusson 1994, Das et al. 1997).

The main objective of this study was to determine the content and its variability of heavy metals such as cadmium, lead, copper and zinc in soils lying in Olkusz District. The correlation between concentrations of particular metals was also taken into consideration. The above problems are crucial not only in the context of the well-developed regional agriculture, but also because of the significant economic transition in the region, which puts emphasis on the development of services, including tourism.

The District of Olkusz is situated in the south of Poland, in Małopolska Province. It is an example of an area occupied by industries and farming, and exposed to heavy metal contamination due to the activity of local industrial plants, of which the largest are the Bolesław Mining and Metallurgy Company and the Emalia Enamelware Factory. Another reason is the influx of toxic substances from industrial plants of the neighbouring Silesian conurbation (DuDKA et al. 1995, Verner et al. 1996, UllRICH et al. 1999). In addition, the analyzed area is covered with an admittedly moderately developed road grid, which nonetheless carries heavy traffic. Despite these facts, the share of farmland in the district is approximately $46 \%$ of the total area (BIEŃKOwsKA et al. 2005, TARADEJNA et al. 2011). It is also worth mentioning that the soil of north-western districts of Małopolska (including Olkusz District), despite the region's most severe potential exposure to contamination, is not monitored by the Regional Inspectorate for Environmental Protection in Kraków, and the last screening of chemistry of Polish arable soils was conducted in 2010 - 2012 by the Chief Inspectorate for Environmental Protection (PAJẠK 2008, SiEBIELEC 2012). 


\section{MATERIAL AND METHODS}

In 2010-2013, determinations of zinc, lead, cadmium, copper in arable soils in selected areas of Olkusz District were conducted. The sampling sites were located within a 10-km radius from Olkusz (Figure 1). All the sites lay near national and local roads (5 to $10 \mathrm{~m}$ from the roadside).

All the samples were collected from arable land, which is not the subject of any form of nature protection. The samples were collected to the depth of $0.3 \mathrm{~m}$ below the land surface (topsoil). In every sampling site, up to 15 subsamples were collected from a square of approximately $20 \times 20 \mathrm{~m}$ in size, and aggregated to obtain a bulk sample, weighting up to $1 \mathrm{~kg}$. The bulk soil samples were air-dried, crushed and sieved through a sieve with the mesh size of $2 \mathrm{~mm}$. Afterwards, every primary sample was divided into four equal parts. Three quarters of each sample were discarded and the remaining quarter called a laboratory sample was used for analysis. Approximately $3 \mathrm{~g}$ of each sample weighed to the nearest $0.0001 \mathrm{~g}$ was mineralized in aqua regia according to ISO norm no. 11466:1995 (ISO 1995). The resulting solution was assayed for the total content of heavy metals $(\mathrm{Zn}, \mathrm{Pb}, \mathrm{Cd}, \mathrm{Cu})$ with flame atomic absorption spectrometry according to ISO norm no. 11047:1998 (ISO 1988), using a Perkin Elmer apparatus AAnayst 300. Each sample was submitted to three determinations, and the average value as well as the relative standard deviation of each sample were calculated. In order to validate the method for accuracy and precision, certified reference material

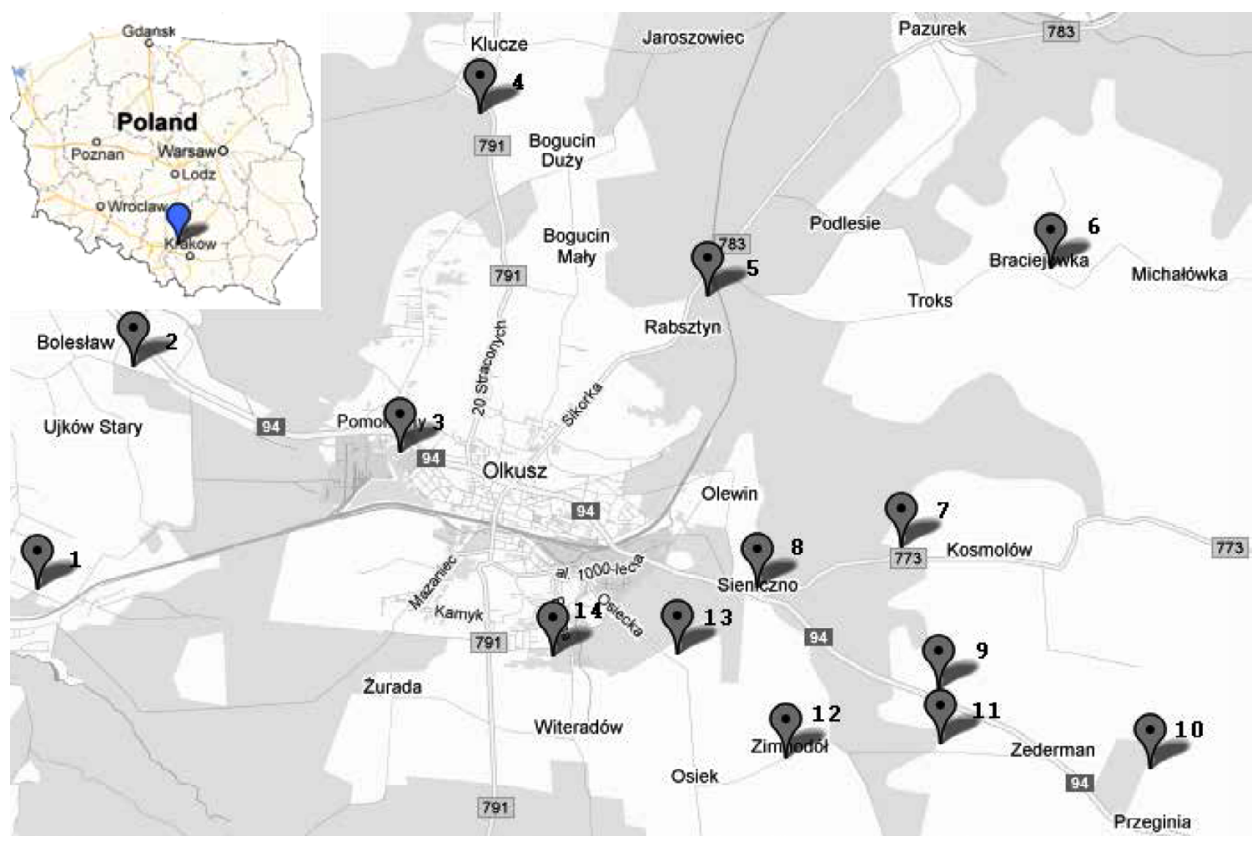

Fig. 1. Sampling sites (basic map data from $@ 2012$ Google) 
(CRM044-50G TRACE METALS - SILT LOAM 1) was analysed in an analogous manner for the corresponding elements. The recoveries were as follows: zinc - 84\%, copper - 98\%, lead - 102\%, cadmium - 105\%.

In addition, some soil parameters were determinated as well:

- the $\mathrm{pH}$ was measured in $1 \mathrm{~mol} \mathrm{dm}^{-3}$ potassium chloride solution, according to ISO norm no. 10390:2005 (ISO, 2005) using an Elmetron CP-401 pH meter device;

- the clay fraction content was determinated by the Bouyoucos areometric method with the Casagrande and Proszynski modification (RYŻAK et al. 2009);

- the organic matter content was estimated using 30\% solution of hydrogen peroxide according to the EPA protocol (Schumacher 2002).

\section{RESULTS AND DISCUSSION}

The analyzed cultivated soils were classified as Luvisols according to the World Reference Base for Soil Resources classification (MARCInEK, KomisareK 2011). The $\mathrm{pH}$ of the tested soils showed they were from medium acidic to moderately alkaline (Table 1). The measurements of the grain-size composition showed that the content of clay fraction in most samples did not exceed 10\% (there were two exceptions: the sites Bolesław and Braciejowka, where the clay content was $14.2 \%$ and $13.6 \%$, respectively). The content of organic matter was lower than $5 \%$ in all the samples. The analyses of the acidity, the clay fraction content and organic matter classified thirteen out of the fourteen analyzed samples as group A of soils (vulnerable to contamination), while one soil (No. 2 - Bolesław) belonged to group B (less vulnerable to contamination), according to the division proposed by the Institute of Soil Science and Plant in Puławy - IUNG (Kabata-Pendias et al. 1995). The classification mentioned above enables one to assess the extent of soil contamination with heavy metals taking their bioavailability into account, as well as to calculate the comprehensive indicator (CI) of soil pollution similarly to the calculations performed in the report on the state of the environment in Małopolska (PAJAूK 2008). The concentrations obtained for the metals are presented in Table 1.

Different authors present slightly different values of the average content of heavy metals in Polish and European soils. The widely assumed average concentration of zinc in non-polluted soils is approximately $40 \mathrm{mg} \mathrm{kg}^{-1}$; for copper this value is about $6.5 \mathrm{mg} \mathrm{kg}^{-1}$ of dry mass (Wilson, MALISzEWSKA-KoRDYBACH 2000). Other frequently cited authors (LIS, PASIECZNA 1995) estimate the content of lead and cadmium at 25 and $0.5 \mathrm{mg} \mathrm{kg}^{-1}$ of dry mass, respectively. In every sample studied, those average values were exceeded by the determined content of zinc and lead. The same was true about cadmium in 13 out of 14 samples and copper in 9 out of 14 samples. 
The average content of heavy metals in particular samples ( $\left.\mathrm{mg} \mathrm{kg}^{-1} \mathrm{~d} . \mathrm{m}.\right)$

\begin{tabular}{|c|c|c|c|c|c|c|c|}
\hline \multirow{2}{*}{$\begin{array}{l}\text { No. of } \\
\text { sam- } \\
\text { pling } \\
\text { sites }\end{array}$} & \multirow{2}{*}{$\begin{array}{l}\text { Location } \\
\text { of sam- } \\
\text { pling } \\
\text { sites }\end{array}$} & \multirow{2}{*}{$\begin{array}{l}\text { Sample } \\
\text { name }\end{array}$} & \multirow{2}{*}{$\begin{array}{c}\mathrm{pH} \\
\mathrm{KCl}\end{array}$} & \multicolumn{4}{|c|}{ Concentration (mg kg$\left.{ }^{-1} \mathrm{~d} . \mathrm{m}.\right)$} \\
\hline & & & & $\mathrm{Zn}$ & $\mathrm{Pb}$ & $\mathrm{Cu}$ & $\mathrm{Cd}$ \\
\hline 1 & \multirow{4}{*}{$\begin{array}{l}\text { W and } \\
\text { NW } \\
\text { of the } \\
\text { Olkusz }\end{array}$} & Bukowno & 7.1 & $12740 \pm 610$ & $404 \pm 15$ & $32.4 \pm 3.3$ & $15.6 \pm 0.8$ \\
\hline 2 & & Boleslaw & 6.8 & $796 \pm 42$ & $152 \pm 7$ & $12 \pm 3$ & $3.58 \pm 0.36$ \\
\hline 3 & & Olkusz & 5.7 & $341 \pm 21$ & $142 \pm 7$ & $12 \pm 1$ & $2.79 \pm 0.14$ \\
\hline 4 & & Klucze & 4.9 & $134 \pm 11$ & $62.8 \pm 4.2$ & $8 \pm 2$ & $1.31 \pm 0.07$ \\
\hline 5 & \multirow{2}{*}{$\begin{array}{l}\text { E of the } \\
\text { Olkusz }\end{array}$} & Rabsztyn & 6.9 & $300 \pm 20$ & $152 \pm 7$ & $12 \pm 3$ & $2.21 \pm 0.12$ \\
\hline 6 & & Braciejowka & 5.0 & $149 \pm 12$ & $95.2 \pm 5.2$ & $10 \pm 1$ & $2.25 \pm 0.12$ \\
\hline 7 & \multirow{8}{*}{$\begin{array}{l}\text { SE of the } \\
\text { Olkusz }\end{array}$} & Kosmołów & 6.3 & $134 \pm 11$ & $97.1 \pm 5.3$ & $5.1 \pm 1.5$ & $0.65 \pm 0.04$ \\
\hline 8 & & Sieniczno & 7.5 & $110 \pm 10$ & $60.5 \pm 4.1$ & $5.6 \pm 2.7$ & $1.18 \pm 0.07$ \\
\hline 9 & & Kogutek & 6.1 & $70 \pm 8$ & $63.1 \pm 4.2$ & $5.1 \pm 0.9$ & $0.79 \pm 0.05$ \\
\hline 10 & & Przeginia & 5.3 & $66.6 \pm 7.2$ & $52 \pm 4$ & $5.8 \pm 0.6$ & $0.55 \pm 0.03$ \\
\hline 11 & & Zederman & 7.0 & $157 \pm 12$ & $82 \pm 5$ & $8 \pm 3$ & $1.70 \pm 0.09$ \\
\hline 12 & & Zimnodól & 6.8 & $96 \pm 9$ & $49 \pm 4$ & $12 \pm 3$ & $0.23 \pm 0.05$ \\
\hline 13 & & Osiek & 6.6 & $120 \pm 10$ & $53 \pm 4$ & $8 \pm 2$ & $0.56 \pm 0.06$ \\
\hline 14 & & Witeradów & 4.8 & $110 \pm 10$ & $73.3 \pm 4.5$ & $5.4 \pm 0.7$ & $1.11 \pm 0.06$ \\
\hline \multicolumn{4}{|c|}{ Median } & 134 & 82.47 & 8.1 & 1.31 \\
\hline \multicolumn{4}{|c|}{ Mean } & 1170 & 113 & 10 & 2.6 \\
\hline \multicolumn{4}{|c|}{ Minimum } & 66.6 & 49.25 & 5.05 & 0.23 \\
\hline \multicolumn{4}{|c|}{ Maximum } & 12740 & 403.82 & 32.38 & 15.63 \\
\hline \multicolumn{4}{|c|}{ Standard deviation } & 3481.8 & 95.33 & 7.14 & 4.05 \\
\hline \multicolumn{4}{|c|}{$\begin{array}{l}\text { Number of samples exceeding the } \\
\text { national limits (ZeLICHOWSKI 2002) }\end{array}$} & $3-4$ & $4-6$ & 0 & 1 \\
\hline
\end{tabular}

However, there are also two standards in Poland describing concentration of heavy metals in soil:

- Regulation of the Ministry of Environment on standards for soil quality (ŻELICHOWSKI 2002),

- Classification proposed by the IUNG from Puławy (Kabata-Pendias et al. 1995).

The national limits for soil are established to be $4 \mathrm{mg} \mathrm{kg}^{-1}$ for Cd, $150 \mathrm{mg}$ $\mathrm{kg}^{-1}$ for $\mathrm{Cu}, 100 \mathrm{mg} \mathrm{kg}^{-1}$ for $\mathrm{Pb}$, and $300 \mathrm{mg} \mathrm{kg}^{-1}$ for $\mathrm{Zn}$ (ŻelichowsKi 2002). The highest excess of the ministry's standards for lead and zinc was observed in the north-western part of the region, near the mining and metallurgy company. In the most contaminated sample no. 1, the zinc content was more than forty-fold higher than the standard, while lead and cadmium surpassed the set limits by more than four-fold. The standards for zinc and lead 
concentrations were also exceeded in the soil samples from Bolesław, Olkusz and Rabsztyn. No excess of the copper concentration was observed, although the content of this metal in sample no.1 was a few times higher than in the other samples (Table 1).

According to the the IUNG classification, the picture of soil contamination with heavy metals is slightly different. This classification categorises soils according to their suitability for farming. It takes into account three more parameters, apart from the concentration of particular metal, namely the $\mathrm{pH}$ of soil, the content of the clay fraction and the organic matter content in soil (KaBATA-PENDiAs et al. 1995).

The degrees of contamination (according to the IUNG) in terms of each of the metals studied and the comprehensive indicator (CI) of soil pollution are presented in Table 2.

In the case of zinc and lead, in every sample the presence of these metals was beyond the natural degree of contamination $\geq{ }^{\circ} \mathrm{I}$ (KABATA-PENDIAS et al. 1995). Moreover, in more than 85\% (12 samples) in the case of zinc and over 57\% (8 samples) in the case of lead, the contamination was so high that crop cultivation should be ruled out for at least some vegetables (degree of contamination $\geq^{\circ} \mathrm{II}$ ). Soil from Bukowno should be completely excluded from

Table 2

The acidity and degree of contamination with heavy metals of the samples

\begin{tabular}{|c|c|c|c|c|c|c|c|}
\hline \multirow[b]{2}{*}{$\begin{array}{l}\text { No. of } \\
\text { the sam- } \\
\text { pling site }\end{array}$} & \multirow[b]{2}{*}{ Sample name } & \multirow[b]{2}{*}{$\begin{array}{l}\text { Group } \\
\text { by } \\
\text { KABATA- } \\
\text {-PENDIAS } \\
\text { et al. } \\
(1995)\end{array}$} & \multicolumn{5}{|c|}{ Degree of contamination by the IUNG } \\
\hline & & & $\mathrm{Zn}$ & $\mathrm{Pb}$ & $\mathrm{Cd}$ & $\mathrm{Cu}$ & $\begin{array}{c}\text { CI of soil pollution, } \\
\text { including } \\
\mathrm{Cd}+\mathrm{Cu}+\mathrm{Pb}+\mathrm{Zn} \\
\text { based on } \\
\text { PAJĄK (2008) }\end{array}$ \\
\hline 1 & Bukowno & $\mathrm{A}$ & $\mathrm{V}$ & III & V & II & $\mathrm{V}$ \\
\hline 2 & Boleslaw & $\mathrm{B}$ & III & II & III & 0 & III \\
\hline 3 & Olkusz & $\mathrm{A}$ & III & III & III & 0 & III \\
\hline 4 & Klucze & $\mathrm{A}$ & II & I & $\mathrm{I}$ & 0 & II \\
\hline 5 & Rabsztyn & $\mathrm{A}$ & II / III & III & III & $0 / \mathrm{I}$ & III \\
\hline 6 & Braciejówka & $\mathrm{A}$ & II & II / III & III & 0 & III \\
\hline 7 & Kosmołów & $\mathrm{A}$ & II & II / III & I & 0 & II / III \\
\hline 8 & Sieniczno & $\mathrm{A}$ & II & I & II & 0 & II \\
\hline 9 & Kogutek & $\mathrm{A}$ & I & I & I & 0 & I \\
\hline 10 & Przeginia & $\mathrm{A}$ & $\mathrm{I}$ & $\mathrm{I}$ & $\mathrm{I}$ & 0 & $\mathrm{I}$ \\
\hline 11 & Zederman & $\mathrm{A}$ & II & II & II & 0 & II \\
\hline 12 & Zimnodół & $\mathrm{A}$ & I / II & I & 0 & 0 & I / II \\
\hline 13 & Osiek & $\mathrm{A}$ & II & I & I & 0 & II \\
\hline 14 & Witeradów & $\mathrm{A}$ & II & I / II & II & 0 & II \\
\hline
\end{tabular}


agricultural production $\left({ }^{\circ} \mathrm{V}\right.$ of contamination). Similar conclusions refer to the cadmium concentration. Only in one sample the $\mathrm{Cd}$ content was natural ( ${ }^{\circ} 0$ of contamination). In 8 sampling points, the content of this metal was ranked in the second and higher degree of contamination. Again, sample no.1 was unsuitable for any agricultural use. In the case of copper, the situation was different. In 12 of the 14 measuring points, the concentration of this element was harmless to agricultural production. In the remaining two cases, the content of copper is only slightly elevated.

The calculated Pearson's correlation coefficients between concentrations of particular metals ranged from 0.93 for $\mathrm{Zn}-\mathrm{Pb}$ and $\mathrm{Zn}-\mathrm{Cu}$ to 0.97 for $\mathrm{Pb}-\mathrm{Cd}$ and 0.98 for $\mathrm{Zn}-\mathrm{Cd}$, depicting strong correlation between concentrations of the four metals, regardless of the concentration. The correlation between concentrations of the heavy metals and the amount of the clay fraction and $\mathrm{pH}$ of the soils turned proved insignificant in these cases $(r \approx 0.3$ and $r \approx-0.25$ respectively). Due to the fact that all the samples turned out to be very poor in organic matter, the correlation between the organic matter and heavy metal content may have been affected by a large random error and cannot be considered as a reliable.

One should stress difficulties in estimating the impact of the parent rock on the final concentration of the metals in the topsoil (STUCZYNSKI et al. 2003). However, there is some evidence of the dominant impact of pollution resulting from prolonged exposure of these soils to industrial emissions. First of all, the emitters of industrial and municipal combustion processes, which prevail in the emission of heavy metals in Poland, are situated mainly in the more populated southern part of the country (DUDKA et al. 1995, STAszeWski et al. 2012, DęBSKI 2013). The spatial distribution of concentrations of the measured pollutants (higher in the west, lower in the southeast of the studied area - Table 1) suggests that quantities of heavy metals deposited in soil by local emitters (mainly from the Bukowno smelter in the Bolesław Mining and Metallurgy Company), in this case, are supplemented by the transboundary influx of contaminants with prevailing S-W and W winds (Woś 2010). This observation is coherent with the studies of STAszewski et al. (2012) based on the condition of soils of Ojców National Park, which is adjacent to the east of the studied area, or with the conclusions of Verner and co-authors (VERNER et al. 1996), who claim that local stack emission plays the major role in soil pollution of an area adjacent to the west of Olkusz District. Moreover, studies of the soils in Silesia conducted in the 1990's revealed an average two- to three-fold higher metal concentration in the topsoil than in the subsoil, supporting the hypothesis about a non-lithogenic source for the contamination (VERNER et al. 1996, UlLRICH et al. 1999). 


\section{CONCLUSIONS}

The soils studied in this work can be classified as moderately and highly polluted with heavy metals, especially with zinc, lead and cadmium. A slight decrease in the concentrations of $\mathrm{Zn}, \mathrm{Pb}$ and $\mathrm{Cd}$ may be observed when comparing the current data with the historical results from the early 1990s from the region around the village Bukowno (VERNER et al. 1996). However, they still exceed most of the Polish standards. The heavy metal contamination is much more severe than in similar urban and rural regions in Europe, e.g. in Belgium (De Temmerman et al. 2003), northern Serbia (ŠKrbić, Đurišić-Mladenović 2013), northwest Croatia (SollitTo et al. 2010) or even in central and western Poland (Grzebisz et al. 2002, Waroszewski et al. 2009, JAWORSKa, DĄBKowska-NASKRĘT 2012). The reported values of heavy metal concentrations are even higher than recorded in such urban areas as the Kraków agglomeration (PAJAK 2008). As mentioned above, the worst pollution was observed in the western, more densely populated, part of the region and in the north of Olkusz. The high concentration of heavy metals in acidic soils (which make up more than half of the tested samples) is particularly dangerous because of the possible transformation of metals into ions, which are more easily assmilated by crops. This concerns mainly such mobile ions as $\mathrm{Cd}^{2+}$ and $\mathrm{Zn}^{2+}$. Our studies have shown that the strongest impact on soil pollution is still exerted by the local industries, although the impact of Silesia, a region lying on average about 30 kilometres west of the sampling points, on the soil contamination is noticeable due to prevailing western and southwestern winds in southern Poland. Statistically significant correlations between the concentrations of all the analyzed metals indicate the same or similarly located sources of pollution. In conclusion, each of these pollutants can be suggested as an indicator reflecting the present effect of industrial and non-industrial emission on the arable soil of the region.

The study case of soils of Olkusz District, which is an example of both industrial and agricultural area, shows that such types of regions are as vulnerable to contamination as industrial and highly urbanized areas. The results also raise concerns because, despite the unquestionable persistent pollution, the analyzed region maintains well-developed agriculture, arboriculture and beekeeping. Therefore, continuous monitoring of this area including the dissemination of information about the risk is required, especially as the region is gradually transforming from industrial economy to services, including tourism.

\section{REFERENCES}

Bergmann H., Machelett B., Lippmann B., Friedrich Y. 2001. Influence of heavy metals on the accumulation of trimethylglycine, putrescine and spermine in food plants. Amino Acids, 20: 325-329. DOI: $10.1007 / \mathrm{s} 007260170048$

Bieńkowska A., Szpadel M., Bigosińska I., RypuŁa K., Dziedzińska K., Madera G. 2005. The area 
of agricultural land in Olkusz County. Central Statistical Office, Warszawa. http://stat.gov. pl/bdlen/app/strona.html?p_name=indeks

Choi Y., Hu H., Mukherjee B., Miller J., Park S.K. 2012. Environmental Cadmium and Lead Exposures and Hearing Loss in U.S. Adults: The National Health and Nutrition Examination Survey, 1999 to 2004. Environ. Health Perspect., 120:1544-1550. DOI:10.1289/ ehp.1104863

Das P., Samantaray S., Rout G. R. 1997. Studies on cadmium toxicity in plants: A review. Environ. Pollut., 98: 29-36. DOI: 10.1016/S0269-7491(97)00110-3

De Temmerman L., Vanongeval L., Boon W., Hoenig M., Geypens M. 2003. Heavy metal content of arable soils in northern Belgium. Water Air Soil Poll., 148: 61-76. DOI: 10.1023/A:1025498629671

Dębski B. 2013. Poland 's Informative Inventory Report 2013. Warsaw: National Centre for Emissions Management., 16-17, 25-26, http://www.kobize.pl/materialy/Inwentaryzacje_krajowe/2012/IIR_Poland_2012.pdf

Dudka S., Piotrowska M., Chlopecka A., Witek T. 1995. Trace metal contamination of soils and crop plants by the mining and smelting industry in Upper Silesia, South Poland. J. Geochem. Explor., 52: 237-250. DOI: 10.1016/0375-6742(94)00047-F

Grzebisz W., Cieśla L., Komisarek J., Potarzycki J. 2002. Geochemical assessment of heavy metals pollution of urban soils. Pol. J. Environ. Stud., 11: 493-499. http://www.pjoes.com/ pdf/11.5/493-499.pdf

HAAR G. L. T., BAYARd M. A. 1971. Composition of airborne lead particles. Nature, 232: 553-554. DOI: $10.1038 / 232553 a 0$

ISO 1988. Soil quality - Determination of cadmium, chromium, cobalt, copper, lead, manganese, nickel and zinc - Flame and electrothermal atomic absorption spectrometric methods. Geneva: International Organization for Standarization.

ISO 1995. Soil quality - Extraction of trace elements soluble in aqua regia Geneva: International Organization for Standarization.

ISO 2005. Soil quality - Determination of pH. Geneva: International Organization for Standarization.

Jaworska H., Dąikowska-Naskręt H. 2012. Influence of the Gtogów copper works on the content of mobile forms of copper and zinc in arable soils. J. Elem., 17(1): 57-66. DOI: 10.5601/ jelem.2012.17.1.05

Kabata-Pendias A., Piotrowska M., Motowicka-Terelak T., Maliszewska-Kordybach B., Filipiak K., Krakowiak A., Pietruch C. 1995. The fundamentals of assessment of chemical contamination of soils. Heavy metals, sulfur and PAHs, Warszawa, IUNG, 15-19. (in Polish)

Kim N. D., Fergusson J. E., 1994. The concentrations, distribution and sources of cadmium, copper, lead and zinc in the atmosphere of an urban environment. Toxicol. Lett., 144: 179-189. DOI: 10.1016/0048-9697(94)90437-5

Lis J., Pasieczna A. 1995. Geochemical atlas of Poland, Warsaw. Polish Geological Institute, 48-49, 73-79.

Marcinek J., Komisarek J. (ed.). 2011. Taxonomy of the Polish soils. Soil Sci. Ann, 62(3): 1-193. (in Polish)

PAJAK B. E. 2008. Report on the state of the environment in Malopolska in 2007. Kraków: The Regional Inspectorate for the Environment Protection in Kraków,155-173. (in Polish) http://www.krakow.pios.gov.pl/publikacje/raporty/raport07/5_gleby.pdf

Ryżak M., Bartmiśski P., Bieganowski A. 2009. Methods for determination of particle size distribution of mineral soils. Acta Agrophys., 175: 48-51. (in Polish) http://www.old.acta-agrophysica.org/en/monograph.html?stan=detail\&paper $=1322$

Satarug S., Baker J. R., Urbenjapol S., Haswell-Elkins M., Reilly P. E., Williams D. J., Moore M. R. 2003. A global perspective on cadmium pollution and toxicity in non-occupationally exposed population. Toxicol. Lett., 137: 65-83. DOI: 10.1016/S0378-4274(02)00381-8 
Schumacher B. A. 2002. Methods for the determination of total organic carbon (TOC) in soils and sediments. Las Vegas: Environmental Protection Agency. http://epa.gov/esd/cmb/research/papers/bs116.pdf

Siebielec G., Smreczak B., Kuimkowicz-Pawlas A., Maliszewska-Kordybach B., Terelak H., Koza P., Hryńczuk B., Łysiak M., Miturski T., Gałazka R., Suszek B. 2012. The monitoring of the chemistry of Polish arable soils in 2010-2012. Puławy: IUNG, 4-25. (in Polish) http://www. gios.gov.pl/zalaczniki/artykuly/Monitoring_sprawozd_koncowe2.pdf

ŠKrbić B., Đurišić-Mladenović N. 2013. Distribution of heavy elements in urban and rural surface soils: the Novi Sad city and the surrounding settlements, Serbia. Environ. Monit. Assess., 185: 457-471. DOI: 10.1007/s10661-012-2567-3

Solanki R., Dhankhar R. 2011. Biochemical changes and adaptive strategies of plants under heavy metal stress. Biologia, 66: 195-204. DOI: 10.2478/s11756-011-0005-6

Sollitto, D., Romic M., Castrignano A., Romic D., Bakic H. 2010. Assessing heavy metal contamination in soils of the Zagreb region (Northwest Croatia) using multivariate geostatistics. Catena, 80: 182-194. DOI: 10.1016/j.catena.2009.11.005

Staszewski T., Łukasik W., Kubiesa P. 2012. Contamination of Polish national parks with heavy metals. Environ. Monit. Assess., 184: 4597-4608. DOI: 10.1007/s10661-011-2288-z

Stuczynski T.I., McCarty G.W., Siebielec G. 2003. Response of soil microbiological activities to cadmium, lead, and zinc salt amendments. J. Environ. Qual., 32(4): 1346-55. DOI: 10.2134/ jeq2003.1346

Taradejna U., Korczak-Żydaczewska K., Milusz M., Wójcikowska J., Sznejder A., Marczak M. 2011. Area and population in the territorial profile in 2011. Statistical Information and Elaborations. Warszawa, Central Statistical Office, 20-21.

Ullrich S. M., Ramsey M. H., Helios-Rybicka E. 1999. Total and exchangeable concentrations of heavy metals in soils near Bytom, an area of Pb/Zn mining and smelting in Upper Silesia, Poland. Appl. Geochem., 14(2): 187-196. DOI: 10.1016/S0883-2927(98)00042-0

Verner J. F., Ramsey M. H., Helios-Rybicka E., Jędrzejczyk B. 1996. Heavy metal contamination of soils around a Pb-Zn smelter in Bukowno, Poland. Appl. Geochem., 11(1-2): 11-16. DOI: $10.1016 / 0883-2927(95) 00093-3$

WaAlkes M. P. 2000. Cadmium carcinogenesis in review. J. Inorg. Biochem., 79: 241-244. DOI: 10.1016/S0162-0134(00)00009-X

Waroszewski J., Kabąa C., Szopka K. 2009. Trace elements in soils of upper zone of spruce forest on Szrenica Mount and the Kowarski Grzbiet range in the Karkonosze Mountains. J. Elem., 14(4): 805-814. DOI: 10.5601/jelem.2009.14.4.805-814

Wilson M., Maliszewska-Kordybach B. (Eds.) 2000. Soil quality, sustainable agriculture and environmental security in Central and Eastern Europe. Nato Science Partnership Subseries, 2(69): 38-42.

Woś. A. 2010. Climate of Poland in the second half of the 20th century. Poznań, Adam Mickiewicz University Press, 90-100. (in Polish)

ŻeLichowski S. 2002. The regulation on standards for soil quality and ground quality standards. Warszawa. Polish Ministry of the Environment. (in Polish) http://isap.sejm.gov.pl/ DetailsServlet?id=WDU20021651359 